\title{
THE CHANGE OF LAND COVER/LAND USE IN EJINA OASIS OVER 20 YEARS
}

\author{
Xiaoyou Zhang ${ }^{1}$, Tongtong Men ${ }^{1}$, Maoxian Zhou ${ }^{1}$ \\ ${ }^{1}$ Cold and Arid Region Environmental and Engineering Research Institute, Chinese Academy \\ of Sciences, Lanzhou 730000, China) \\ * Corresponding author, Address: Cold and Arid Region Environmental and Engineering \\ Research Institute, Chinese Academy of Sciences, Lanzhou 730000, Gansu Province, P.R \\ China.Tel: +86-931-4967146,Email: zhangxy@lzb.ac.cn
}

Abstract: Land use and land cover change have been of great concern in global change research in recent years. Base on comparison with the remote sensing data in1982 and 2000 and field investigation, the results of land cover and land use change were obtained by the method of landscape analysis. Ten types of land use were identified: riparian woods, riparian shrubbery, desert shrubbery, desert grassland, river-way and water area, salinised land, town, Gobi, shift sand dune, denudative upland. The results show that, (1) there were obvious Changes in land cover structure. The area of riparian woods decreased $0.97 \%$ and the number of patch decrease 376; The area of riparian shrubbery increased $0.92 \%$ and the number of patch decreased 1316. Meanwhile, the index of \%LAND of desert shrubbery increased from $4.49 \%$ to $5.65 \%$; Because of decrease of water quantity of discharge from middle reach. The patch of river-way and water area decreased from 40 to 6 . The index of $\%$ LAND decreased $0.15 \%$.At the same time, the index of \% LAND of shift sand dune increased $0.42 \%$. (2) the area of riparian woods dominated by Populus euphratica and desert grassland decreased to $45.02 \%$ and $14.55 \%$. However, the areas of riparian shrubbery dominated by Tamarix SPP and desert shrubbery increase to $35.03 \%$ and $25.88 \%$. The transition probability is $45.95 \%$ from riparian woods to riparian shrubbery. at the same time, they are $0.78 \%$ and $3.01 \%$ from riparian woods to desert $\rightarrow$ shrubbery and desert $\rightarrow$ grassland. The succession trend of ecosystem was obtained: riparian woods riparian shrubbery and grassland desert grassland. Meanwhile, the succession velocity becomes higher and higher.

Key words: Ejina oasis, land ecology, Spatial distribution

Please use the following format when citing this chapter:

Zhang, X., Men, T. and Zhou, M., 2009, in IFIP International Federation for Information Processing, Volume 293, Computer and Computing Technologies in Agriculture II, Volume I, eds. D. Li, Z. Chunjiang, (Boston: Springer), pp. 59-67. 
Land Use/Land Cover Change, LUCC is noticed in current international research area, was set for core project by international Geosphere and Biosphere Project programme (IGBP) and International Human Dimensions Programme (IHDP) (Tuner II B L.,1990; Meyer W B, et al., 1994). It is quite important in global or local environment changes and continual development. Land use and land cover change is the most intimate question between nature and human, it is the embodiment of relationship of human being and earth. Water, soil, air, biology and topographic condition are the main compositions of region ecological environment, which change and interact each other, determinate region land ecology types and evolution characteristic (Jorgenson M T, 1999; Wang Genxu, et al., 2001). With the higher development of the satellite remote sensing technology and space information system, there are great progresses in quantitative investigation between the spatial feature of land surface with modern process, which analyzed the driving factors of ecological environment variation, and provided quantification's research approach for ecological environment protection and construction program (Li Xiubin. et al., 1996; Shi Peijun, et al., 2001). Landscape change equal to land translate in many situations, it include land use and land cover change, which are the main base to divide landscape, and landscape heterogeneity which has intimate relationship with land beset. It will be more and more important to research land retirement and vegetative cover succession for region ecological environment in landscape ecology.

Ejin locates at the catchment area of Heihe River, it is in the most western of Nei Mongolia autonomous region, the total area is 114.6 thousand $\mathrm{km}^{2}$. Ejin is a animal husbandry border county where the Mongolia Race of Torguts tribal descendant is main part. Total population only 15.7 thousand, among of which agro-animal husbandry population is 3.5 thousand. Ejin oasis is located flat basin in the middle of Ejin. The upstream water of Heihe River is alone water source which maintains Ejin oasis. As a result of the middle reaches of Heihe River over-development and overutilize water resource, taking the land desertification, the vegetation degenerates as representative's ecological environment worsen has affected seriously the downstream desert oasis and restricts economy of river basin and society's sustainable development. Ejin ecological environment has been worsened, it includes the blocking the flow, the terminal lake vanished, the lowering of groundwater table, the vegetation degeneration, the natural oasis withering, the land desertification rapid development, the sand source appearing in oasis interior, the sand storm aggravating harm. Not only this causes the region environment to worsen and the biological species reduction, but also has threatened the entire river basin and the peripheral localities ecological security and the environment condition. Because the strategic status of Ejin to be special, therefore we must research the inner 
link between the water resources and the oasis, rescue Ejin oasis, control ecological environment in the round, it will be significant and the profound significance for the border area stable, the territorial integrity, the national unity as well as west develops.

\section{THE GENERAL SITUATION OF RESEARCH REGION AND THE APPROACH}

\subsection{The general situation of research region and ecology type division}

This scope of research region is: Ejina oasis approximately situates between $99^{\circ} 03$ '- $100^{\circ} 00^{\prime}$ E, $40^{\circ} 30^{\prime}$ - $42^{\circ} 30^{\prime}$ ' W, is a part of Alasan Platform, is a large alluvial fan of the termination of Heihe River. Its east is close to Badain Jaran Desert, west is the Mazong mountainous region, north to the Chinese and Mongolian boundary, south to Dingxin Oasis whose area is 31.2 thousand $\mathrm{km}^{2}$ at the upper extreme of Heihe downstream. According to the ecology region division, it belongs to the temperate zone warm temperate zone arid desert area Alashan High Plain sub-region. Arid is the basic climate characteristic in this region ecosystem, also is the region unique ecosystem structure. Based on the land ecosystem division principle, the oasis ecological environment system may be divided: The riparian forest ecosystem including riparian woods which Populus euphratica is main part and riparian shrubbery which Tamarix SPP is main, it occupies $4.7 \%$ of the oasis area; Desert steppe ecosystem including the desert shrubbery and the desert steppe, it accounts for $16.3 \%$; The water area, including the seasonal rivers and the lake, accounts for $0.2 \%$; Other difficultly to use land, including Sandy land, Gobi, salina land and low hill, accounts for $78.8 \%$.

Populus euphratica, Elaeagnus angustifolia, Tamarix sp., Phragmites communis, Achnatherum splendens, Sophora alopecuroides and Glycyrrhiza uralensis etc.; psammobiontic shrubs and herbs mainly occur in the surrounding desert region of the oasis, they include Haloxylon ammodendron, Hitratria tangutorum, Artemisa sp. and Agriophyllum arenarium etc.; in the arid low mountain hilly areas and vast gobi plain there are sparse drought-tolerant desert vegetation such as Reaumuria soongorica, Nitraria sphaerocarpa, Ephedra przewalskii, Zygophyllum xanthoxylon, Sympegma regelii, Anabasis and Calligonum sp. etc. 
Table 1 the spatial distribution characteristic of oasis and desert in the Ejin

\begin{tabular}{|c|c|c|c|}
\hline NAME & Type & Basic feature & Distribution-phore \\
\hline \multirow{3}{*}{ Ecosystem } & $\begin{array}{l}\text { Riparian } \\
\text { forest }\end{array}$ & $\begin{array}{l}\text { Including Populus euphratica forest, } \\
\text { Populus euphratica and Tamarix SPP } \\
\text { shrubery which the form is priority part, } \\
\text { Sophora alopecuroides and weed as } \\
\text { constructive species and Lycium } \\
\text { ruthenicum, Karelina caspica in partial } \\
\text { place. its structural features are severally } \\
\text { arbour rarity and the age of forest is old, } \\
\text { shrubery live densely, while hassock is } \\
\text { short. Taking Populus euphratica and } \\
\text { Tamarix SPP forest as typical } \\
\text { representative. }\end{array}$ & $\begin{array}{l}\text { Distribute by the spot or the } \\
\text { corridor form in the oasis interior } \\
\text { river-way both sides, assumes } \\
\text { flabelliform, occupies the oasis } \\
\text { area } 4.7 \% \text {, is the main body of the } \\
\text { oasis. }\end{array}$ \\
\hline & $\begin{array}{l}\text { Desert } \\
\text { steppe }\end{array}$ & $\begin{array}{l}\text { The middle Gobi locates between the west } \\
\text { and east river, takes the rarity old age } \\
\text { Populus euphratica as primary, there are } \\
\text { Reaumuria soongorica, Haloxylon } \\
\text { ammodendron and Nitraria tangutorum } \\
\text { under it, only rarity Nitraria sphaerocarpa, } \\
\text { Calligonum sp.in other places, Tamarix sp. } \\
\text { and Phragmites communis in lowland and } \\
\text { on lacustrine beach with good moisture } \\
\text { condition; Take rarity Nitraria tangutorum } \\
\text { and Reaumuria soongorica as typical } \\
\text { representatives. }\end{array}$ & $\begin{array}{l}\text { This type occupies the oasis area } \\
16.3 \% \text {, by belt-shaped or mottling } \\
\text { distribution, in far away river-way } \\
\text { Gobi is the rarity grassland, } \\
\text { Phragmites communis mainly } \\
\text { distributes in Guriner Beach. }\end{array}$ \\
\hline & Waters area & $\begin{array}{l}\text { The area of West Juyan Lake is } 266 \mathrm{~km}^{2} \text {, } \\
\text { East Juyan Lake is } 336 \mathrm{~km}^{2} \text {, some small } \\
\text { lakes and seasonal river-ways. West Juyan } \\
\text { Lake have withered } 63 \text { years, sometimes } \\
\text { there are few excess water in other lakes. }\end{array}$ & $\begin{array}{l}\text { West and East Juyan Lakes locate } \\
\text { in the most north of the oasis, } \\
\text { other lakes in the east and west of } \\
\text { the oasis. }\end{array}$ \\
\hline \multicolumn{2}{|c|}{$\begin{array}{l}\text { Other difficultly to } \\
\text { utilized land } \mathrm{km}^{2}\end{array}$} & $\begin{array}{l}\text { The raletive heights of Fixed, half-fixed } \\
\text { sand dune are smaller than } 20 \mathrm{~m} \text {, there are } \\
\text { rarity tamarix sp; the cover degree of } \\
\text { vegetable in Gobi is below } 3 \% \text {, there are } \\
\text { xeric, extra-xeric Reaumuria soongorica } \\
\text { and so on, there is short life Shacong and } \\
\text { so on in less than } 100 \mathrm{~m} \text { denudative } \\
\text { upland. }\end{array}$ & $\begin{array}{l}\text { Gobi mainly distributes in the } \\
\text { oasis periphery, but fixed and half- } \\
\text { fixed sand dune mainly distribute } \\
\text { in both sides of river-way and the } \\
\text { inner of the oasis, the denudative } \\
\text { upland distributes in Hongger of } \\
\text { eastern and the northwest Fox } \\
\text { mountain. The beach is the } \\
\text { salification meadow soil of } \\
\text { Guriner Lake. }\end{array}$ \\
\hline
\end{tabular}

\subsection{Research approach}

Mainly contrasted and has analyzed the different time remote sensing data and auxiliary by field investigation. Using Landsat TM/ETM remote sensing data is a kind of effective method about region Land use/Land cove 

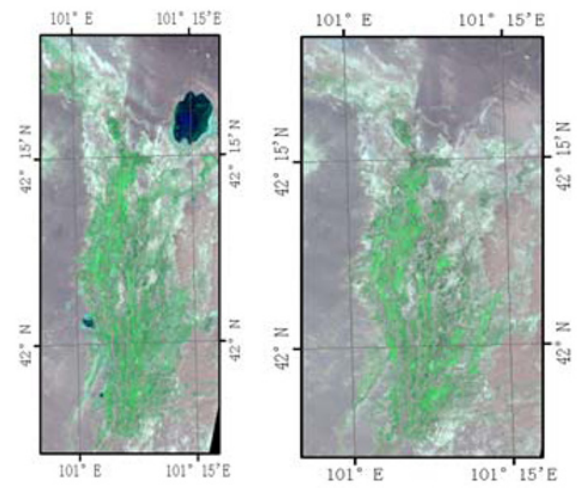

Fig 1 : Remote sensing image of Ejina oasis in 1982 and 2000

\section{SPATIAL DISTRIBUTION AREA CHANGES OF DIFFERENT LAND COVERS}

\subsection{Riparian forest ecosystem Change}

The Riparian forest ecosystem is composed by two parts, one is Populus euphratica forest and riparian woods, which Populus euphratica is as primarily, but Russianolive or Tamarix SPP as the auxiliary; Two is riparian shrubbery, including rarity old age Populus euphratica and densely living Tamarix SPP or Tamarix SPP shrubbery. During 1982-2000, the area of woods seriously shrunk, reduced $1063.0 \mathrm{hm}^{2}$, annual decline rate is $2.51 \%$ in the appraisal year, the overmature forest increased unceasingly in the age of forest structure, sickness and mouldered woods and survives woods increased in the forest form structure. In contrast riparian shrubbery increased, expanded from $2862.5 \mathrm{hm}^{2}$ to $2865.2 \mathrm{hm}^{2}$, the average increment rate is $1.95 \%$ yearly. The riparian forest ecosystem has had the change. This expressed that the riparian forest made from arbor, shrub and grass is inverting to riparian shrubbery composed from shrub and grass. The riparian forest ecosystem structure and function is tending towards simple.

\subsection{Desert steppe ecosystem change}

Desert steppe ecosystem is composed of desert shrubbery and desert grassland. steppe ecosystem be ejin oasis' s important constituent, in the near 20 years, desert shrubbery has increased greatly. But the area of desert grassland reduces unceasingly, achieves $12315.2 \mathrm{hm}^{2}$, the reducing rate of annual mean is $0.81 \%$, the whole area of desert steppe reduces $4.3 \%$, about 
$824.6 \mathrm{hm}^{2}$, is $1.44 \%$, achieves $1272 \mathrm{hm}^{2}$. But the area of desert grassland reduces unceasingly, achieves $12315.2 \mathrm{hm}^{2}$, the reducing rate of annual mean is $0.81 \%$, the whole area of desert steppe reduces $4.3 \%$, about $824.6 \mathrm{hm}^{2}$. Ecosystem structure tends towards simple.

\subsection{Water area change}

The water area includes mainly lake and the river-way. The river is divided into two big branches at Langxin mountain in Ejin oasis, and could be divided 19 branches furthermore. These branches all are the seasonal rivers, can form runoff in flood period or in the winter every year, other period all are the withered river beds, becomes source region of the sand storm. There are 7 lakes In 1982, among which the waters area of the east river's terminal lake is $99 \mathrm{hm}^{2}$, other lakes area is $68.4 \mathrm{hm}^{2}$. In later 20 years, the lakes are successively withered, in the lake base, became the Saline-alkalization sand, in the lake edge, became the mobile sand.

\subsection{Land system of difficult to utilize change}

It can reveal the region ecological environment condition and the evolution direction directly with difficult to utilize land type change; Its increment is the manifestation of land serious degeneration. The land of difficult to utilize area increased continually in the near 20 years. So we can see that the shift sand dune area increased from $762.8 \mathrm{hm}^{2}$ to $1226.1 \mathrm{hm}^{2}$, changed $463.3 \mathrm{hm}^{2}$, the annual mean increment is $3.37 \%$; Secondly, the land of villages and towns increased, which took up the forest land; Next salinised land was reducing, the accumulation reduced was $69.9 \mathrm{hm}^{2}$, because the original salina land had changed into the wind erosion sand by the nature through 20 years.

Table 2:The direction and extent of oasis types transfer in the Ejina

\begin{tabular}{llllc}
\hline Land Use & 1982 & 2000 & $1982-2000$ & Average increase rate $(\%)$ \\
\hline Riparian Woods & 2361.2 & 1298.2 & -1063.0 & -45.02 \\
Riparian Shrubbery & 2862.5 & 3865.2 & 1002.7 & 35.03 \\
Desert Shrubbery & 4917.2 & 6189.9 & 1272.7 & 25.88 \\
Desert Grassland & 14412.6 & 12315.3 & -2097.3 & -14.55 \\
River-way and Water area & 177.4 & 12.9 & -164.5 & -92.73 \\
Salinised Land & 84.9 & 15.0 & -69.9 & -82.33 \\
Town & 34.8 & 46.5 & 11.7 & 33.62 \\
Gobi & 83716.3 & 84363.0 & 646.7 & 0.77 \\
Shift Sand Dune & 762.8 & 1226.1 & 463.3 & 60.74 \\
Denudative Upland & 256.8 & 256.8 & 0 & 0.00 \\
\hline
\end{tabular}




\section{LAND ECOTYPE EVOLUTION}

\subsection{Dispersal area and structural change of land covers}

The \%LAND index (Landscape quadrat area ratio) could display the structural changes of the landscape spatial distribution, The \%LAND index changes of land covers in Ejin oasis is showed in table 3.

Table 3: The \%LAND in index changes of different land cover types of Ejin oasis in 19822000

\begin{tabular}{lllll}
\hline \multirow{2}{*}{ Land Use } & \multicolumn{2}{c}{1982} & \multicolumn{2}{c}{2000} \\
\cline { 2 - 5 } & PATCH & \%LAND & PATCH & \%LAND \\
\hline Riparian Woods & 1888 & 2.15 & 1512 & 1.18 \\
Riparian Shrubbery & 4266 & 2.61 & 2950 & 3.53 \\
Desert Shrubbery & 6454 & 4.49 & 5680 & 5.65 \\
Desert Grassland & 12615 & 13.15 & 11976 & 11.24 \\
River-way and Water area & 40 & 0.16 & 7 & 0.01 \\
Salinised Land & 34 & 0.08 & 64 & 0.01 \\
Town & 6 & 0.03 & 6 & 0.04 \\
Gobi & 5842 & 76.39 & 4910 & 76.98 \\
Shift Sand Dune & 12 & 0.7 & 8 & 1.12 \\
Denudative Upland & 8 & 0.23 & 8 & 0.23 \\
\hline
\end{tabular}

We could see from table 3, the Gobi took up the leadership of spatial distribution, its status didn't change, still occupied $76.39 \% \sim 76.98 \%$ of the oasis area. In the recent 20 years, riparian woods area shrunk $0.97 \%$, the patches decreased 376 , but riparian shrubbery increased $0.92 \%$, the patches decreased 1316; The patches of desert shrubbery and desert grassland decreased unceasingly, but the \%LAND index of desert shrubbery increased from $4.49 \%$ to $5.65 \%$; Because the water inflow from middle reaches decreased sharply, the patches of river-way and water area decreased from 40 to 6 , the \%LAND index decreased $0.15 \%$. The \%LAND index of shift sand dune increased $0.42 \%$ at the same time. Although there wasn't big change in oasis spatial pattern, the riparian forest-sparse shrub-grass structure tended to simple, its ecology function weakened.

\subsection{Ecosystem types shift and change characteristic}

Using 1982 and 2000 remote sensing data, has established the transfer matrix of recent 20 years. The matrix element expressed one kind of landscape divert to another kind of landscape in area proportion. The diagonal value represents area ratio of landscape with self-successive, so we could intuitively see landscape dynamic evolution tendency and the evolved range. The oasis landscape have been diverting to desert landscape in recent 
20 years in Ejin oasis. The transition probability from riparian woods and shrubbery to riparian shrubbery and grassland was as high as $45.95 \%$, to desert shrubbery and rarity grassland were $0.78 \%$ and $3.01 \%$, to Gobi Landscape was $10.87 \%$; the transition probability from riparian shrubbery and grassland to riparian woods and shrubbery was $8.06 \%$, but to desert shrubbery and rarity grassland were $10.95 \%$ and $19.64 \%$, to Gobi was $11.88 \%$; the transition probability from rarity shrubbery to rarity grassland was $21.19 \%$, to Gobi was $3.96 \%$; the transition probability from large area rarity grassland to rarity shrubbery, riparian shrubbery and grassland and riparian woods and shrubbery were $14.05 \%, 3.36 \%, 0.23 \%$ respectively, but to Gobi was $28.13 \%$ 。 The transition probability from river-way and water area to the vegetative landscape was far and away less than to Gobi(desertization) through 20 years evolvement. It can be seen from above data, Ejin's ecology condition was improved in partial and small scope from 1982 to 2000, the whole worsened condition (seeing Table 4).

Table 4: The director and extent of oasis type trans of Ejin in 1982-2000

\begin{tabular}{|c|c|c|c|c|c|c|c|c|c|c|}
\hline \multirow[b]{2}{*}{1982} & \multicolumn{10}{|c|}{2000} \\
\hline & $\begin{array}{c}\text { Riparian } \\
\text { Woods }\end{array}$ & $\begin{array}{l}\text { Riparian } \\
\text { Shrubbery }\end{array}$ & $\begin{array}{c}\text { Desert } \\
\text { Shrubbery }\end{array}$ & $\begin{array}{c}\text { Desert } \\
\text { Grasslan } \\
\text { d }\end{array}$ & $\begin{array}{c}\text { River-way } \\
\text { and Water } \\
\text { area }\end{array}$ & $\begin{array}{c}\text { Salinised } \\
\text { Land }\end{array}$ & Town & Gobi & $\begin{array}{l}\text { Shift } \\
\text { Sand } \\
\text { Dune }\end{array}$ & $\begin{array}{l}\text { Denudativ } \\
\text { Upland }\end{array}$ \\
\hline Riparian Woods & 39.19 & 45.95 & 0.78 & 3.01 & 0.03 & 0.06 & 0.1 & 10.87 & 0 & 0 \\
\hline $\begin{array}{l}\text { Riparian } \\
\text { Shrubbery }\end{array}$ & 8.06 & 49.13 & 10.95 & 19.64 & 0 & 0.11 & 0.09 & 11.88 & 0 & 0 \\
\hline Desert Shrubbery & 0.16 & 1.9 & 72.54 & 21.19 & 0 & 0.02 & 0 & 3.96 & 0.22 & 0 \\
\hline Desert Grassland & 0.23 & 3.36 & 14.05 & 53.57 & 0 & 0.01 & 0.03 & 28.13 & 0.61 & 0 \\
\hline $\begin{array}{l}\text { River-way and } \\
\text { Water area }\end{array}$ & 1.35 & 4.89 & 4.53 & 26.73 & 5.73 & 0.18 & 0.31 & 56.04 & 0.21 & 0 \\
\hline Salinised Land & 0.13 & 1.29 & 6.72 & 50.06 & 0 & 0.23 & 0 & 41.56 & 0 & 0 \\
\hline Town & 0.67 & 1.05 & 0 & 0 & 0 & 0 & 98.14 & 0.03 & 0 & 0 \\
\hline Gobi & 0.12 & 0.93 & 0.3 & 3.38 & 0 & 0.01 & 0 & 94.82 & 0.44 & 0 \\
\hline Shift Sand Dune & 0 & 0 & 0 & 0 & 0 & 0 & 0 & 0.48 & 99.44 & 0 \\
\hline Denudative Uplan & 0 & 0 & 0 & 0 & 0 & 0 & 0 & 0 & 0 & 100 \\
\hline
\end{tabular}

\section{CONCLUSION AND DISCUSSION}

In the recent 20 years, the water volume drained at the beginning of 80 's was 1.174 billion $\mathrm{m}^{3} / \mathrm{a}$, but at the end of 80 's was 0.844 billion $\mathrm{m}^{3} / \mathrm{a}$, the mean drainage was 0.378 billion $\mathrm{m}^{3} / \mathrm{a}$ in the 90 's, only was 0.283 billion $\mathrm{m}^{3}$ in 2000. At the same time the stock capacity of oasis and desert rangeland was maintained at $24 \times 10^{4} \sim 29 \times 10^{4}$ sheep, the overload was $4 \times 10^{4} \sim 4 \times 10^{4}$ sheep in Heihe River. The water volume drained continually decreased, it made that the ecological environment worsened unceasingly, the land use and the land cover had changed fiercely. This became the factor which 
rangeland overloaded continually. Mainly displays in: (1) The riparian woods and desert rarity grassland decreased $45.02 \%$ and $14.55 \%$; (2) The rivers blocked the flow in long time, which caused the lake quantity and the water area decreased sharply, turned into desertification land; (3) Riparian forest and grassland decreasing, caused the shift sand dune area Increased, the annual mean increase was $3.37 \%$. Through the evolution trend, the range and the land cover \%LAND index change, it can be seen that the spatial evolution characteristic of land cover in the recent 20 years. The $60 \%$ of riparian woods and shrubbery which occupied the main part in oasis have changed, the $50 \%$ of shrubbery and grassland have changed, the $27 \%$ of rarity shrubbery and $47 \%$ of rarity grassland have also changed, which occupied larger area in oasis, the water area evolved toward the non-plant growth type. Looked from the overall landscape, the evolvement of Ejin oasis is riparian woods and shrubbery $\rightarrow$ riparian shrubbery and grassland $\rightarrow$ desert rarity shrubbery $\rightarrow$ desert rarity grassland $\rightarrow$ Gobi.

\section{ACKNOWLEDGEMENTS}

This study was funded by the knowledge Innovation Engineering Project of the Chinese Academy of Sciences [KZCX -10-03].

\section{REFERENCES}

Jorgenson M T, Roth J E, Raynolds M K et al .An ecological land survey for Fort Wainwright, Alaska .CRREL Report -9,Alaska :US Army Corps of Engineers 1999.

Li Xiaobin, Chen Yunfeng, Yu Feng. Global and regional cover mapping form remote sensing data: status quo, strategies and trends[J].Advance in earth sciences ,2004,19(1):7178.

$\mathrm{Li}$ Xiaobin. International research on environmental consequence of land use/cover change[J].Advance in earth sciences. 1999,14(4):395-400

Li Xiubin. A review of the international researches on land use/land covers change $\{\mathrm{J} \backslash$.Acta Geographical Sinica, 1996, 51(6):553-558.

Meyer W B, Tuner II B L. Change Use and Land Cover: A Global Perspective [M]. London : Cambridge University Press ,1994.

Shi Peijun, Gong Peng, Li Xiaobing et al, Study Method and Practice on Land use Cover Change (M). Beijing: Science Pree,2000.

Tuner II B L. Two types of global environmental change: definitional and spatial issues in their human dimensions [J].Global Environmental Chang, 1990,1(1):14-22.

Wang Genxu, Qian Ju, Cheng Guodong. Eco-environmental degradation and causal analysis in the source region of the Yellow River ( $\mathrm{J}$ ) .Environmental Geology, 2001,40(7):884890 . 